\title{
Further Evidence on Export-Led Growth in the United Arab Emirates: Are Non-Oil Exports or Re-Exports the Key to Economic Growth?
}

\author{
${ }^{1}$ Middle East Centre, London School of Economics and Political Science, Room PAN.10.01, Pankhurst House, Clement's Inn, \\ London WC2A 2AZ, UK, E-mail: a.kalaitzi@lse.ac.uk \\ ${ }^{2}$ DeGroote School of Business, McMaster University, 1280 Main Street West, Hamilton, Ontario L8S 4M4, Canada, E-mail: \\ chambert@mcmaster.ca
}

\begin{abstract}
:
This study investigates the relationships between exports and economic growth in the United Arab Emirates. Understanding these relationships is important for purposes of establishing appropriate growth and development policies and strategies. The study uses an augmented Cobb-Douglas production function to examine the causality between non-oil exports, re-exports and economic growth over the period 1981-2012. To investigate the existence of a long-run relationship between the variables, the study performs the Johansen cointegration test, while the direction of the short-run causality is examined by applying the Granger causality test in a vector error correction model framework. A modified Wald test in an augmented vector autoregressive model is applied in order to find the direction of the long-run causality. This research provides evidence in support of an indirect short-run uni-directional causality from economic growth to re-exports, through physical capital accumulation and imports. As for long-run causality, the results show that a bi-directional causality exists between re-exports and economic growth in the UAE.
\end{abstract}

Keywords: diversification, re-exports, economic growth, causality, UAE

JEL classification: $\mathrm{O} 47, \mathrm{~F} 43, \mathrm{C} 22$

DOI: 10.1515/rmeef-2019-0007

\section{Introduction}

The relationship between exports and economic growth is an important and sometimes controversial policy issue. Most of the academic studies on this relationship indicate that exports have a positive effect on economic growth through their impact on economies of scale, the adoption of advanced technology and a higher level of capacity utilization (Chenery and Strout 1966; Gylfason 1999; Rodrik 1997). At the same time, some studies have found that exports have a negative effect on economic growth (Myrdal 1957; Meier 1970; Lee and Huang 2002; Kim and Lin 2009), but this negative effect may be observed because in some countries primary exports constitute a large share of total exports. Primary exports are often subject to excessive price fluctuations (Myrdal 1957), and do not offer knowledge spillovers and other externalities as do other export categories (Herzer, Nowak-Lehmann, and Siliverstovs 2006; Kalaitzi and Cleeve 2017).

In the case of the UAE, where primary exports mainly consist of oil exports, fluctuations in oil prices can have a negative long-run effect on economic growth (Sodeyfi and Katircioglu 2016; Katircioglu, Katircioglu, and Altun 2018). This suggests that emphasis should be placed on diversified exports in order to achieve sustained economic growth. Empirical studies have emphasised the important role of diversified exports in economic growth, but a further question is what type of diversification is important. In particular, in the case of the UAE, are non-oil exports or re-exports the key to further economic growth?

Over the period 1981-2012, the UAE experienced significant export diversification and a high rate of economic growth. The country's export diversification is reflected in the increase in non-oil exports and re-exports during the last three decades. The value of non-oil exports increased from US $\$ 500$ million in 1981 to US $\$ 46.2$ billion in 2012, a ninety-fold increase. In addition, the share of non-oil exports in GDP, which averaged less than $1 \%$ in 1981, grew to approximately $12 \%$ in 2012. Further evidence of the UAE's diversification success is that in 2012, it ranked first and sixth in re-exports among Arab countries and globally, respectively (World 
Trade Organization 2012). The value of re-exports in 2012, estimated at around US\$59.5 billion, represented an increase of about 56 times over the 1981 level.

This study identifies and evaluates the causal relationship between diversified exports and economic growth, by shedding further light on the causal effects that non-oil exports and re-exports can have on growth. In the case of the UAE, evidence on the causal relationship between exports and economic growth is limited and mixed, and there is no study on the short-run or long-run causality between non-oil exports, re-exports and economic growth. The study is intended to contribute to the design of future policies for enhancing and sustaining economic growth in the UAE and will be instructive for other countries attempting to emulate the UAE's success.

This study also addresses several issues that have been overlooked in the previous empirical literature. In particular, prior studies have applied unit root tests biased towards the non-rejection of a unit root in the presence of a structural break. Oil-based economies like that of the UAE are subject to oil price shocks. For this reason, in addition to conventional unit root tests, the unit root test with a structural break proposed by Saikkonen and Lütkepohl (2002) is applied to evaluate the time series properties of the data. Another issue that has been typically ignored in previous studies is that Johansen's cointegration test can be biased towards rejecting the null hypothesis of no cointegration for small samples. In order to remedy this issue, the ReinselAhn adjustment is used (Reinsel and Ahn 1992).

Most previous work has used bivariate or trivariate models to test the causality between exports and economic growth, leading to potentially misleading and biased results, inasmuch as causality tests are sensitive to omitted variables. In addition, most recent studies have investigated the existence of a long-run causality between exports and economic growth based on error correction models (ECMs), but the long-run causal effect of each variable on the dependent variable can only be identified in the case of a bivariate ECM. To overcome these problems, this study includes variables omitted in previous studies and applies the Toda-Yamamoto-Granger causality test.

The results of this study suggest that no direct causality exists between non-oil exports or re-exports and economic growth in the short-run. However, there is evidence to support the existence of a bi-directional causality between re-exports and economic growth in the long-run.

The rest of the paper is organized as follows. Section 2 presents the literature on the relationship between exports and economic growth. Section 3 presents chosen methodology, data sources and empirical models. Section 4 reports and interprets the empirical results. Finally, Section 5 presents the conclusions and policy implications of this research.

\section{Literature Review}

The relationship between exports and economic growth is a frequent topic of discussion when economists try to explain the different levels of economic growth among countries. Early studies noted the positive impact of export expansion on economic growth. Chenery and Strout (1966) and Gylfason (1999) showed that an increase in exports causes a broad expansion of imports of services and capital goods, which are essential to improving productivity, while the increasing inflows of technology have positive effects on economic growth. In addition, Rodrik (1997) notes that the rate of economic growth is affected by the rate of exports, because of the increase in investments in export-oriented firms and in those that cover the increasing domestic demand.

In more recent years, several studies have investigated the direction of causality between exports and economic growth, as determining the causal pattern between these variables has important implications for growth strategies. The majority of these studies conclude that causality runs from exports to economic growth and that what is referred to as export-led growth (ELG) exists. The growth of exports increases the inflow of foreign exchange, enabling the country to import capital goods necessary for economic growth. At the same time, imports are considered to be a major channel for technology transfer and knowledge diffusion, which are essential to improving productivity and accelerating economic growth (Ghatak, Milner, and Utkulu 1997; Ramos 2001; Awokuse 2003; Shirazi and Abdul Manap 2004; Siliverstovs and Herzer 2006; Ferreira 2009; Gbaiye et al. 2013).

In contrast, other studies indicate that causality runs from growth to exports and that the growth-led export (GLE) hypothesis is valid (El-Sakka and Al-Mutairi 2000; Panas and Vamvoukas 2002; Love and Chandra 2005; Mishra 2011). In particular, further increases in economic growth lead to export expansion, by increasing the country's capacity to finance imports used as inputs for export-oriented production. Moreover, some studies conclude that a bi-directional causal relationship exists (ELG-GLE) between exports and economic growth, where one reinforces the other (Abu-Qarn and Abu-Bader 2004; Awokuse 2007; Elbeydi, Hamuda, and Gazda 2010). In contrast, other studies provide evidence of no causality between exports and economic growth (Jung and Marshall 1985; Kwan and Cotsomitis 1991; Tang 2006; Kalaitzi 2018). 
In addition, a few studies suggest that exports have a negative impact on economic growth. Berrill (1960) notes that export expansion can retard the development of small developing countries, while Chaudhuri (1989) indicates that exports can be an obstacle to further growth in low-income countries that specialize in the production of labour-intensive goods. This negative effect may be due to a large share of primary exports in total exports, as this category of exports can be subject to excessive price fluctuations and does not offer knowledge spillovers in the way manufactured exports do (Myrdal 1957; Herzer, Nowak-Lehmann, and Siliverstovs 2006; Kalaitzi and Cleeve 2017). This has led to some studies investigating the impact of export categories on economic growth, as aggregate measures may mask the different causal effects of subcategories of exports. In particular, Tuan and Ng (1998), Abu-Qarn and Abu-Bader (2004), Herzer, Nowak-Lehmann, and Siliverstovs (2006), Hosseini and Tang (2014), and Kalaitzi and Cleeve (2017) examine the effect of export composition on economic growth, and find that not all exports affect economic growth equally.

Tuan and $\mathrm{Ng}$ (1998) examine the long-run relationship between trade and economic growth in Hong Kong over the period 1961-1995, using the Johansen cointegration test and vector error correction model (VECM). In their study, trade is measured by total exports, domestic exports and re-exports, while GDP is used as a proxy for economic growth. As Tuan and $\mathrm{Ng}(1998,125)$ note, "while no long-run relationship seemingly exists between growth of GDP and total exports, the growth of GDP and export trade are related by components". Their results show that a $1 \%$ increase in real domestic exports and in real re-exports increased GDP by $0.7 \%$ and $0.2 \%$, respectively, indicating that "manufacturing operations would have much higher value-added contents than trading firms" (Tuan and Ng 1998, 128).

Abu-Qarn and Abu-Bader (2004) investigate the relationship between exports and economic growth for nine Middle East and North Africa (MENA) countries during various periods based on data availability. The methodology used in their research includes the Johansen cointegration test and the Granger causality test in an empirical framework of trivariate systems. The variables used are real GDP, real total exports, real manufactured exports and real imports taken at constant prices in local currencies. The results of the study demonstrate that not all exports contribute equally to economic growth and that the promotion of manufactured exports in the MENA region could accelerate economic growth.

Herzer, Nowak-Lehmann, and Siliverstovs (2006) examine the ELG hypothesis for Chile over the period 1960-2001, using the Engle-Granger cointegration test and the Granger causality test in a VECM framework. The variables used in their study are real imports, real exports of manufactured goods and real primary exports as proxies for exports, and real non-export output as a proxy for economic growth. Their results indicate that manufactured exports and exports of primary products have a statistically positive and negative impact on economic growth, respectively. The authors conclude that "manufactured exports might offer greater potential for knowledge spillovers and other externalities than primary exports" (325).

Hosseini and Tang (2014) investigate the causal relationship between oil and non-oil exports in Iran, using Johansen's cointegration test and the Granger causality test in a VECM framework. Their study is based on a two-input production function augmented with oil exports, non-oil exports and imports of goods and services, using annual data over the period 1970-2008. The cointegration results indicate that a long-run relationship exists between capital, labour, oil exports, non-oil exports and imports, and all variables except oil exports and imports are found to have a positive effect on economic growth. Moreover, the study shows that oil exports and non-oil exports Granger cause economic growth, indicating that the ELG hypothesis is valid in the short-run in the case of Iran. In addition, bi-directional causality is found between imports and economic growth, and between capital and economic growth, both in the short-run.

Kalaitzi and Cleeve (2017) investigate the causality between primary exports, manufactured exports and economic growth in the UAE over the period 1981-2012, using an augmented Cobb-Douglas production function. Their study applies the Johansen cointegration test, the Granger causality test in a VECM framework and a modified version of the Wald test in an augmented vector autoregressive model. The cointegration results indicate that manufactured exports contribute more to economic growth than do primary exports in the longrun. Their study also provides evidence to support a bi-directional causality between manufactured exports and economic growth in the short-run and finds that the GLE hypothesis is valid in the long-run.

Previous studies have examined the effect of export composition on economic growth, and have found that not all exports affect economic growth equally. Three studies have investigated the effect of exports on economic growth in the UAE, but only one of them, Kalaitzi and Cleeve (2017), examined the effect of disaggregated exports. Studies by Al-Yousif (1997) and El-Sakka and Al-Mutairi (2000) investigate the relationship between aggregate exports and economic growth in the UAE, but their results are contradictory. Al-Yousif (1997) examines the existence of a long-run relationship between exports and economic growth in four Arab Gulf countries, including the UAE, over the period 1973-1993. His study uses an augmented production function with exports, government expenditure and terms of trade, and applies the two-step cointegration technique and regression analysis. The results indicate that there is no long-run relationship between exports and economic growth in 
the UAE and the other countries under investigation, while exports positively affect economic growth in the short-run for all of the selected Gulf countries.

El-Sakka and Al-Mutairi (2000) examine the relationship between exports and growth in Arab countries, using bivariate Granger causality tests. Their study confirms the results of Al-Yousif (1997) regarding the nonexistence of a long-run relationship between exports and economic growth for all countries examined, but indicates that short-run causality runs from growth to exports in the case of the UAE (for the period 19721996). As for short-run causality between exports and economic growth in the other countries studied, the results are mixed. In particular, a uni-directional causality runs from exports to growth in Saudi Arabia, Iraq, Morocco and Syria, while a bi-directional causality exists between exports and growth in Oman, Algeria, Egypt, Jordan, Bahrain and Mauritania. Moreover, the results show no causality between exports and growth in the case of Kuwait, Qatar, Libya, Tunisia and Sudan. There is thus no agreement on whether exports cause economic growth in the Arab World.

It should be noted that Al-Yousif (1997) claims to provide evidence on the validity of the ELG, using a regression equation. This study is based on the statistical significance of the coefficients of the export variables, but this is not an appropriate way to draw conclusions about the causal relationship between exports and economic growth, as regression analysis shows only the effect and not the cause. Moreover, the estimation of a single equation ignores the existence of interrelationships and suffers from a mis-specification problem, as causality does not necessarily run from exports to economic growth. In addition, the study by El-Sakka and Al-Mutairi (2000) uses a bivariate model to test the ELG hypothesis, but this may lead to misleading and biased results, as causality tests are sensitive to omitted variables. To overcome this problem, the present study includes variables omitted in previous studies, such as capital accumulation, population and imports of goods and services, together with multivariate causality tests.

Moreover, the majority of the more recent studies investigates the existence of long-run causality in an ECM context (Herzer, Nowak-Lehmann, and Siliverstovs 2006; Awokuse 2007; Mishra 2011; Hosseini and Tang 2014). However, in the case of multivariate ECMs, it is not possible to indicate which explanatory variable causes the dependent variable in the long-run. The causal effect of each variable on the dependent variable can only be identified in the short-run. Also, the test of a long-run relationship based on ECMs requires pre-testing of the cointegrating rank and this may result in overrejection of the non-causal null, due to pre-test biases. For this reason, this study uses the Toda-Yamamoto-Granger causality test, following Kalaitzi and Cleeve (2017), overcoming the limitations of previous studies.

In addition, based on evidence that primary exports do not offer knowledge spillover effects (Herzer, NowakLehmann, and Siliverstovs 2006; Kalaitzi and Cleeve 2017) and that oil prices exert negative long-run effects on real income (Sodeyfi and Katircioglu 2016; Katircioglu, Katircioglu, and Altun 2018), the focus is placed on diversified exports. This study extends the work of Kalaitzi and Cleeve (2017), by shedding further light on the causal effects of deeper disaggregated exports on economic growth in the UAE. To do so, the export components are further disaggregated into non-oil exports and re-exports and the following tests are applied: (a) unit root tests in order to ensure that all variables included in the model are stationary; (b) a cointegration test to confirm the existence of a long-run relationship between exports and economic growth; (c) the multivariate Granger causality test to find the direction of the short-run causality; and (d) a modified Wald test (MWALD) in an augmented vector autoregressive model to investigate the long-run causality between exports and economic growth.

\section{Data and Methodology}

\subsection{Data}

This research uses annual time series for the UAE over the period 1981-2012, obtained from national and international sources. Specifically, gross domestic product $(Y)$ is taken from the World Development IndicatorsWorld Bank, while population (HC), non-oil exports (NOILX) and re-exports (REX) are obtained from the National Bureau of Statistics of the UAE. The data series for imports of goods and services (IMP) and gross fixed capital formation $(K)$ are taken from IMF, National Bureau of Statistics and World Bank sources. All variables are expressed in logarithmic form and real terms, using the GDP deflator taken from the World Bank. The descriptive statistics and plots of the log-transformed data are shown in Table 1 and Figure 1, respectively.

Table 1: Descriptive statistics for the period 1981-2012.

\begin{tabular}{lllllll}
\hline Statistics & $L Y$ & $L K$ & LHC & LNOILX & LREX & LIMP \\
\hline
\end{tabular}




\begin{tabular}{lllllll} 
Mean & 25.734 & 24.020 & 14.831 & 22.028 & 23.134 & 24.792 \\
Median & 25.716 & 23.896 & 14.743 & 21.903 & 23.188 & 24.735 \\
Maximum & 26.355 & 24.883 & 16.035 & 24.239 & 24.538 & 26.061 \\
Minimum & 25.144 & 23.293 & 13.885 & 20.660 & 21.454 & 23.745 \\
Std. dev. & 0.401 & 0.523 & 0.653 & 0.981 & 0.956 & 0.777 \\
Jarque-Bera & 2.610 & 2.629 & 2.160 & 2.050 & 1.725 & 2.236 \\
(probability) & 0.271 & 0.269 & 0.340 & 0.359 & 0.422 & 0.327 \\
Observations & 32 & 32 & 32 & 32 & 32 & 32 \\
\hline
\end{tabular}

${ }^{1}$ Authors' calculations

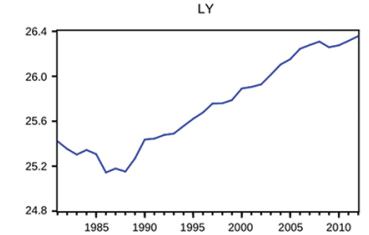

LNOLXX
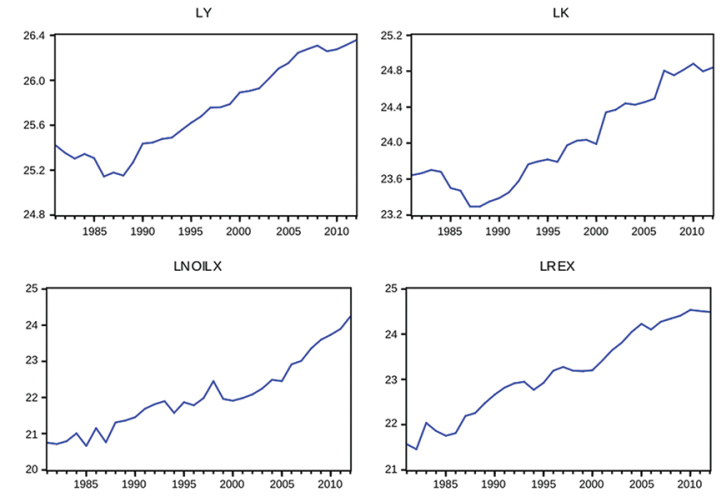

LREX

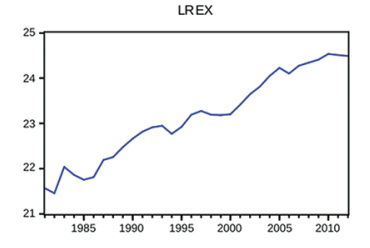

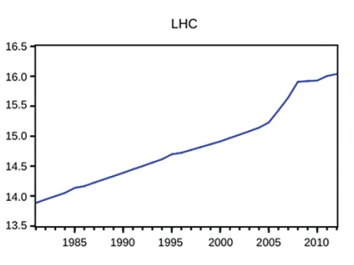

LMP

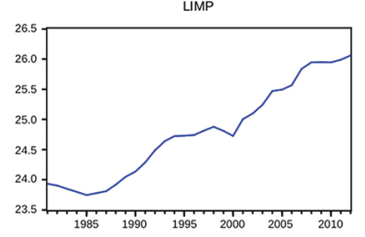

Figure 1: Pattern of the logarithm of the time-series over the period 1981-2012. The figure is created by the authorsSource: Gross Domestic Product is taken from the WDI-World Bank, Gross Fixed Capital Formation and Imports are taken from the IFS-IMF (years 1999-2000 are taken from the UAE National Bureau of Statistics and years 2010-2012 are taken from the World Bank). Non-oil Exports, Re-exports and Population are taken from the UAE National Bureau of Statistics. The graphs are produced using the econometric software Eviews/9.

\subsection{Methodology}

This paper examines whether diversified exports cause economic growth, assuming that the aggregate production of the economy can be expressed as a function of physical capital, human capital, imports, non-oil exports and re-exports. The study follows Tuan and Ng (1998) and Hosseini and Tang (2014) in defining the export variables used in the following model:

$$
Y_{t}=A_{t} K_{t}^{\alpha} H C_{t}^{\beta}
$$

where $Y_{t}$ denotes the aggregate production of the UAE economy at time $t, A_{t}$ is total factor productivity, while $K_{t}$ and $H C_{t}$ represent physical capital and human capital, respectively. The constants $\alpha$ and $\beta$ measure the shares of physical and human capital in income. As stated above, in order to test the relationship between non-oil exports, re-exports and economic growth, it is assumed that total factor productivity can be expressed as a function of non-oil exports, NOILX $_{t}$, re-exports, $R E X_{t}$, imports of goods and services, IMP , and other exogenous factors, $C_{t}$ :

$$
A_{t}=f\left(N_{\text {NOILX }}, \operatorname{REX}_{t}, I M P_{t}, C_{t}\right)=\operatorname{NOILX}_{t}^{\gamma} \operatorname{REX}_{t}^{\delta} I M P_{t}^{\zeta} C_{t}
$$

Combining eqs. (1) and (2) yields

$$
Y_{t}=C_{t} K_{t}^{\alpha} H C_{t}^{\beta} N O I L X_{t}^{\gamma} R E X_{t}^{\delta} I M P_{t}^{\zeta}
$$

where $\alpha, \beta, \gamma, \delta$ and $\zeta$ represent the elasticities of production with respect to the inputs of production: $K_{t}, H C_{t}$, NOILX $_{t}, R E X_{t}$ and IMP . After taking the natural logs of both sides of eq. (3), we obtain

$$
L Y_{t}=c+\alpha L K_{t}+\beta L H C_{t}+\gamma L N O I L X_{t}+\delta L R E X_{t}+\zeta I M P_{t}+\varepsilon_{t}
$$

where $\mathrm{c}$ is the intercept, the coefficients $\alpha, \beta, \gamma, \delta$ and $\zeta$ are constant elasticities, while $\varepsilon_{\mathrm{t}}$ is the error term, which reflects the influence of factors not included in the model. 


\subsubsection{Unit Root Test}

The augmented Dickey-Fuller (ADF) test is conducted in order to test for the presence of a unit root (Enders 1995). The ADF test is based on the following:

$$
\begin{gathered}
\Delta \mathrm{Y}_{\mathrm{t}}=\gamma \mathrm{Y}_{\mathrm{t}-1}+\sum_{i=1}^{p} \beta \mathrm{i} \Delta \mathrm{Y}_{\mathrm{t}-\mathrm{i}}+\varepsilon_{\mathrm{t}} \\
\Delta \mathrm{Y}_{\mathrm{t}}=\alpha_{0}+\gamma \mathrm{Y}_{\mathrm{t}-1}+\sum_{i=1}^{p} \beta \mathrm{i} \Delta \mathrm{Y}_{\mathrm{t}-\mathrm{i}}+\varepsilon_{\mathrm{t}} \\
\Delta \mathrm{Y}_{\mathrm{t}}=\alpha_{0}+\gamma \mathrm{Y}_{\mathrm{t}-1}+\alpha_{2} \mathrm{t}+\sum_{i=1}^{p} \beta \mathrm{i} \Delta \mathrm{Y}_{\mathrm{t}-\mathrm{i}}+\varepsilon_{\mathrm{t}}
\end{gathered}
$$

where $\alpha_{0}$ and $\alpha_{2}$ represent the deterministic elements.

Equation (5) is a random walk, eq. (6) is a random walk with intercept only, and eq. (7) is a random walk with intercept and time trend (Gujarati 2003). In addition, the random errors are assumed to be uncorrelated and identically distributed with zero mean and variance $\sigma^{2}\left\{\varepsilon_{t} \sim \mathrm{ii}\left(0, \sigma^{2}\right)\right.$ for $\left.t=1,2, \ldots.\right\}$. In each case, the null hypothesis is that $\gamma=0 ; \mathrm{H}_{\mathrm{o}}$ : unit root exists, while the alternative hypothesis is that $\gamma<0 ; \mathrm{H}_{\mathrm{a}}$ : unit root does not exist.

In addition, this research applies the Phillips and Perron (1988) unit root test, which is a generalization of the Dickey-Fuller procedure that allows for heteroscedasticity and serial correlation in the error terms (Enders 1995). The test involves the following:

$$
\begin{gathered}
\mathrm{Y}_{\mathrm{t}}=\gamma_{0}^{*}+\gamma_{1}^{*} \mathrm{y}_{\mathrm{t}-1}+\mu_{\mathrm{t}} \\
\mathrm{Y}_{\mathrm{t}}=\gamma_{0}^{*}+\gamma_{1}^{*} \mathrm{y}_{\mathrm{t}-1}+\gamma_{2}^{*}(\mathrm{t}-\mathrm{T} / 2)+\mu_{\mathrm{t}}
\end{gathered}
$$

where $\gamma_{0}^{*}$ and $\gamma_{2}^{*}$ are the deterministic elements, $\mathrm{T}$ is the number of observations, while $\mu_{\mathrm{t}}$ is the error term. The ADF and PP tests are performed by following the method suggested by Dolado, Jenkinson, and Sosvilla-Rivero (1990) regarding the inclusion of the constant and trend.

It should be noted that if there are structural breaks in the data, the ADF and PP test statistics are biased toward the non-rejection of a unit root. As a result, a structural break is identified as evidence of non-stationarity. The UAE economy was subject to oil shocks during the period 1981-2012. For this reason, the Saikkonen and Lütkepohl (2002) unit root test with a structural break (SL) is applied. The SL test involves the following:

$$
\begin{gathered}
\mathrm{Y}_{\mathrm{t}}=\mu_{\mathrm{o}}+\gamma \mathrm{Y}_{\mathrm{t}-1}+\mu_{1} \mathrm{t}+\delta \mathrm{d}_{1 \mathrm{t}}+u_{\mathrm{t},} \\
\mathrm{Y}_{\mathrm{t}}=\mu_{\mathrm{o}}+\gamma \mathrm{Y}_{\mathrm{t}-1}+\delta \mathrm{d}_{1 \mathrm{t}}+u_{\mathrm{t},}
\end{gathered}
$$

where $\mu_{0}$ is the constant term, $\mu_{1}$ and $\delta$ are the coefficients of the trend term and the shift dummy variable, respectively, while $u_{\mathrm{t}}$ is the error term. In addition, $\mathrm{d}_{1 \mathrm{t}}$ is a shift dummy variable with break date $\mathrm{T}_{\mathrm{break}}: \mathrm{d}_{1 \mathrm{t}}=0$, for $\mathrm{t}<\mathrm{T}_{\text {break }}$ and $\mathrm{d}_{1 \mathrm{t}}=1$, for $\mathrm{t}>\mathrm{T}_{\text {break }}$.

\subsubsection{Cointegration Test}

The study applies the Johansen cointegration test (Johansen 1988, 1995) in order to confirm the existence of a long-run relationship between the variables. Johansen's methodology estimates the cointegrating vectors using a maximum likelihood procedure, taking its starting point in a VAR of order $\mathrm{p}$ given by

$$
X_{t}=\mu+\sum_{i=1}^{p} A_{i} X_{t-i}+\varepsilon_{t}
$$

where

$X_{t}$ is an $(n \times 1)$ vector of variables which are $I(1), \mu$ is an $(n \times 1)$ vector of constants, $A_{i}$ is an $(n \times n)$ matrix of parameters, while $\varepsilon_{t}$ is an $(n \times 1)$ vector of random errors. Subtracting $X_{t-1}$ from each side and letting I be an $(n \times n)$ identity matrix, 


$$
\Delta X_{t}=\mu+\Pi X_{t-1}+\sum_{i=1}^{p-1} \Gamma_{i} \Delta X_{t-i}+\varepsilon_{t}
$$

where $\Gamma_{i}=-\sum_{j=i+1}^{p} A_{j}$ and $\Pi=\sum_{i=1}^{p} A_{i}-$ I. $\Gamma_{\mathrm{i}}$ and $\Pi$ are the coefficient matrices, $\Pi \mathrm{X}_{t-1}$ is the error-correction term, while the coefficient matrix $\Pi$ provides information about the long-run relationships among the variables. The number of long-run relationships can be determined by using the likelihood ratio (LR) trace test statistic suggested by Johansen (1988). The LR trace statistic is adjusted for small sample size, as proposed by Reinsel and Ahn $(1992)^{1}$, and is as follows:

$$
\mathrm{J}_{\text {trace }}=-\mathrm{T} \sum_{i=r+1}^{n} \ln (1-\lambda i),
$$

where $T$ is the sample size and $\lambda$ is the eigenvalue. The trace test tests the null hypothesis of at most $r$ cointegrating vectors against the alternative hypothesis of $n$ cointegrating vectors.

It is important to note that the inclusion of too few lags in the cointegration test could lead to rejection of the null hypothesis, while too many lags could decrease the power of the test (Verbeek 2012). For this reason, the lag length for the system is determined by minimizing the Schwarz information criterion (SIC). In addition to the selection of the optimal lag length, the inclusion of a time trend should be considered when testing for cointegration. In order to determine the best model, Pantula's (1989) principle is used.

\subsubsection{Short-run Granger Causality Test}

The VAR model, developed by Sims (1980), is used to investigate whether non-oil exports or re-exports cause economic growth in the UAE. In the VAR model, all variables are treated as endogenous, while no current variables appear on the right-hand side of the equations. The VAR model with six endogenous variables $\left(L Y_{t}\right.$, $L K_{t}, H C_{t}$, LNOILX $_{t}$, LREX $_{t}$, LIMP $_{t}$ ) can be expressed as follows:

$$
\begin{aligned}
& L Y_{t}=\alpha_{10}+\sum_{j=1}^{p} \beta_{1 j} L Y_{t-j}+\sum_{j=1}^{p} \gamma_{1 j} L K_{t-j}+\sum_{j=1}^{p} \delta_{1 j} L H C_{t-j}+\sum_{j=1}^{p} \zeta_{1 j} L_{N O I L X} \\
& +\sum_{j=1}^{p} \theta_{1 j} L_{R E X_{t-j}}+\sum_{j=1}^{p} \mu_{1 j} \operatorname{LIMP}_{t-j}+\varepsilon_{1 t} \\
& L K_{t}=\alpha_{20}+\sum_{j=1}^{p} \beta_{2 j} L Y_{t-j}+\sum_{j=1}^{p} \gamma_{2 j} L K_{t-j}+\sum_{j=1}^{p} \delta_{2 j} L H C_{t-j}+\sum_{j=1}^{p} \zeta_{2 j} L_{N O I L X_{t-j}} \\
& +\sum_{j=1}^{p} \theta_{2 j} L R E X_{t-j}+\sum_{j=1}^{p} \mu_{2 j} L I M P_{t-j}+\varepsilon_{2 t} \\
& L H C_{t}=\alpha_{30}+\sum_{j=1}^{p} \beta_{3 j} L Y_{t-j}+\sum_{j=1}^{p} \gamma_{3 j} L K_{t-j}+\sum_{j=1}^{p} \delta_{3 j} L H C_{t-j}+\sum_{j=1}^{p} \zeta_{3 j} L_{N O I L X_{t-j}} \\
& +\sum_{j=1}^{p} \theta_{3 j} L_{R E X_{t-j}}+\sum_{j=1}^{p} \mu_{3 j} L I M P_{t-j}+\varepsilon_{3 t} \\
& \text { LNOILX }_{t}=\alpha_{40}+\sum_{j=1}^{p} \beta_{4 j} L Y_{t-j}+\sum_{j=1}^{p} \gamma_{4 j} L K_{t-j}+\sum_{j=1}^{p} \delta_{4 j} L H C_{t-j}+\sum_{j=1}^{p} \zeta_{4 j} \text { LNOILX }_{t-j} \\
& +\sum_{j=1}^{p} \theta_{4 j} L R E X_{t-j}+\sum_{j=1}^{p} \mu_{4 j} L I M P_{t-j}+\varepsilon_{4 t} \\
& \text { LREX }_{t}=\alpha_{50}+\sum_{j=1}^{p} \beta_{5 j} L Y_{t-j}+\sum_{j=1}^{p} \gamma_{5 j} L K_{t-j}+\sum_{j=1}^{p} \delta_{5 j} L H C_{t-j}+\sum_{j=1}^{p} \zeta_{5 j} L_{N O I L X_{t-j}} \\
& +\sum_{j=1}^{p} \theta_{5 j} L R E X_{t-j}+\sum_{j=1}^{p} \mu_{5 j} L I M P_{t-j}+\varepsilon_{5 t} \\
& \operatorname{LIMP}_{t}=\alpha_{60}+\sum_{j=1}^{p} \beta_{6 j} L Y_{t-j}+\sum_{j=1}^{p} \gamma_{6 j} L K_{t-j}+\sum_{j=1}^{p} \delta_{6 j} L H C_{t-j}+\sum_{j=1}^{p} \zeta_{6 j} L_{N} N O I L X_{t-j} \\
& +\sum_{j=1}^{p} \theta_{6 j} L R E X_{t-j}+\sum_{j=1}^{p} \mu_{6 j} L I M P_{t-j}+\varepsilon_{6 t}
\end{aligned}
$$

where $L Y_{t}, L K_{t}, L H C_{t}, L N O I L X_{t}, L R E X_{t}$ and LIMP $t$ represent the variables of the proposed model (eq. (4)); $\beta_{i j}$, $\gamma_{i j}, \delta_{i j}, \zeta_{i j}, \theta_{i j}, \mu_{i j}$ are the regression coefficients; and $p$ is the optimal lag length, selected by minimising the value of the Schwartz information criterion (SIC). It should be noted that exogenous variables can be added to the VAR model without adding equations to the system. Here, a dummy is included when it is necessary for the stability of the model.

Moreover, if the variables are found to be cointegrated, which is the most common case for macroeconomic variables, the following restricted VAR model (VECM) can be used to find the direction of the causality: 


$$
\begin{aligned}
\Delta L Y_{t}= & \sum_{j=1}^{p} \beta_{1 j} \Delta L Y_{t-j}+\sum_{j=1}^{p} \gamma_{1 j} \Delta L K_{t-j}+\sum_{j=1}^{p} \delta_{1 j} \Delta L H C_{t-j}+\sum_{j=1}^{p} \zeta_{1 j} \Delta L N O I L X_{t-j} \\
+ & \sum_{j=1}^{p} \theta_{1 j} \Delta L R E X_{t-j}+\sum_{j=1}^{p} \mu_{1 j} \Delta L I M P_{t-j}-\lambda_{y} E C T_{t-1}+\varepsilon_{1 t} \\
\Delta L K_{t}= & \sum_{j=1}^{p} \beta_{2 j} \Delta L Y_{t-j}+\sum_{j=1}^{p} \gamma_{2 j} \Delta L K_{t-j}+\sum_{j=1}^{p} \delta_{2 j} \Delta L H C_{t-j}+\sum_{j=1}^{p} \zeta_{2 j} \Delta L N O I L X_{t-j} \\
+ & \sum_{j=1}^{p} \theta_{2 j} \Delta L R E X_{t-j}+\sum_{j=1}^{p} \mu_{2 j} \Delta L I M P_{t-j}-\lambda_{k} E C T_{t-1}+\varepsilon_{2 t} \\
\Delta L H C_{t}= & \sum_{j=1}^{p} \beta_{3 j} \Delta L Y_{t-j}+\sum_{j=1}^{p} \gamma_{3 j} \Delta L K_{t-j}+\sum_{j=1}^{p} \delta_{3 j} \Delta L H C_{t-j}+\sum_{j=1}^{p} \zeta_{3 j} \Delta L N O I L X_{t-j} \\
+ & \sum_{j=1}^{p} \theta_{3 j} \Delta L R E X_{t-j}+\sum_{j=1}^{p} \mu_{3 j} \Delta L I M P_{t-j}-\lambda_{h c} E C T_{t-1}+\varepsilon_{3 t} \\
\Delta L N O I L X_{t} & =\sum_{j=1}^{p} \beta_{4 j} \Delta L Y_{t-j}+\sum_{j=1}^{p} \gamma_{4 j} \Delta L K_{t-j}+\sum_{j=1}^{p} \delta_{4 j} \Delta L H C_{t-j}+\sum_{j=1}^{p} \zeta_{4 j} \Delta L N O I L X_{t-j} \\
& +\sum_{j=1}^{p} \theta_{4 j} \Delta L R E X_{t-j}+\sum_{j=1}^{p} \mu_{4 j} \Delta L I M P_{t-j}-\lambda_{n o i l x} E C T_{t-1}+\varepsilon_{4 t} \\
\Delta L R E X_{t}= & \sum_{j=1}^{p} \beta_{5 j} \Delta L Y_{t-j}+\sum_{j=1}^{p} \gamma_{5 j} \Delta L K_{t-j}+\sum_{j=1}^{p} \delta_{5 j} \Delta L H C_{t-j}+\sum_{j=1}^{p} \zeta_{5 j} \Delta L N O I L X_{t-j} \\
& +\sum_{j=1}^{p} \theta_{5 j} \Delta L R E X_{t-j}+\sum_{j=1}^{p} \mu_{5 j} \Delta L I M P_{t-j}-\lambda_{r e x} E C T_{t-1}+\varepsilon_{5 t} \\
\Delta L I M P_{t}= & \sum_{j=1}^{p} \beta_{6 j} \Delta L Y_{t-j}+\sum_{j=1}^{p} \gamma_{6 j} \Delta L K_{t-j}+\sum_{j=1}^{p} \delta_{6 j} \Delta L H C_{t-j}+\sum_{j=1}^{p} \zeta_{6 j} \Delta L N O I L X_{t-j} \\
& +\sum_{j=1}^{p} \theta_{6 j} \Delta L R E X_{t-j}+\sum_{j=1}^{p} \mu_{6 j} \Delta L I M P_{t-j}-\lambda_{i m p} E C T_{t-1}+\varepsilon_{6 t}
\end{aligned}
$$

where $\Delta$ is the difference operator; $\beta_{i j}, \gamma_{i j}, \delta_{i j}, \zeta_{i j}, \theta_{i j}, \mu_{i j}$ and $\lambda_{i j}$ are the regression coefficients; and $E C T_{t-1}$ is the error correction term derived from the cointegration equation.

Once the above equations have been estimated, ${ }^{2}$ the cumulative sum of recursive residuals (CUSUM) and the CUSUM of squares (CUSUMQ) tests are applied in order to assess the parameter constancy of the ECM estimates. Specifically, the CUSUM test detects systematic changes, while the CUSUMQ test detects haphazard changes in the parameters. The CUSUM test proposed by Brown, Durbin, and Evans (1975) is based on the statistic:

$$
\mathrm{W}_{\mathrm{t}}=\sum_{k+1}^{t} w_{t} / \mathrm{s}, \mathrm{t}=\mathrm{k}+1, \ldots \ldots \mathrm{T}
$$

where $s$ is the standard deviation of the recursive residuals $\left(w_{t}\right)$, which is defined as

$$
w_{t}=\left(y_{t}-x^{\prime} b_{t-1}\right) /\left(1+x_{t}^{\prime}\left(X_{t-1}{ }^{\prime} X_{t-1}\right)^{-1} x_{t}\right)^{1 / 2}
$$

The numerator $y_{\mathrm{t}}-x_{\mathrm{t}}{ }_{\mathrm{t}-1}$ is the forecast error, $b_{\mathrm{t}-1}$ is the estimated coefficient vector up to period $t-1$ and $x_{\mathrm{t}}{ }^{\prime}$ is the row vector of observations on the regressors in period $t . X_{\mathrm{t}-1}$ denotes the $(t-1) \times k$ matrix of the regressors from period 1 to period $t-1$. If the $b$ vector changes, $W_{t}$ tends to diverge from a zero mean value, while $E\left(W_{t}\right)=0$ if the $\mathrm{b}$ vector remains constant. The test shows parameter instability if the cumulative sum of the recursive residuals lies outside the area between the two five percent significance lines, the distance between which increases with t.

The CUSUM of squares test uses the squared recursive residuals, $w_{t}{ }^{2}$, and is based on the plot of the statistic:

$$
\mathrm{S}_{\mathrm{t}}=\left(\sum_{k+1}^{t} w_{t}^{2}\right) /\left(\sum_{k+1}^{T} w_{t}^{2}\right), \text { where } \mathrm{t}=\mathrm{k}+1, \ldots \ldots, \mathrm{T}
$$

The expected value of $S_{t}$, under the null hypothesis of the $b_{t}{ }^{\prime} s$ being constant, is $E\left(S_{t}\right)=(t-k) /(T-k)$, which takes values from zero at $t=\mathrm{k}$, to unity at $\mathrm{t}=\mathrm{T}$. In this test the $\mathrm{S}_{\mathrm{t}}$ are plotted together with the $5 \%$ critical lines and, as in the CUSUM test, movements outside the 5\% critical lines for parameter stability indicate instability in the equation during the sample period. If the CUSUM test or CUSUMQ test shows evidence of structural instability, an exogenous variable should be included in order to obtain more efficient estimates.

After assessing the constancy of the estimated parameters, this study applies the multivariate causality test (Granger 1969,1988). The causality from diversified exports to economic growth and vice versa can be examined by conducting a chi-squared test. The following hypotheses are tested: 
$\mathrm{H}_{0}: \sum_{j=1}^{p} \zeta_{1 j}=0$ : Non-oil exports do not Granger cause economic growth.

$\mathrm{H}_{\mathrm{A}}: \sum_{j=1}^{p} \zeta_{1 j} \neq 0$ : Non-oil exports Granger cause economic growth.

$\mathrm{H}_{0}: \sum_{j=1}^{p} \theta_{1 j}=0$ : Re-exports do not Granger cause economic growth.

$\mathrm{H}_{\mathrm{A}}: \sum_{j=1}^{p} \theta_{1 j} \neq 0$ : Re-exports Granger cause economic growth.

$\mathrm{H}_{0}: \sum_{j=1}^{p} \beta_{4 j}=0$ : Economic growth does not Granger cause non-oil exports.

$\mathrm{H}_{\mathrm{A}}: \sum_{j=1}^{p} \beta_{4 j} \neq 0$ : Economic growth Granger causes non-oil exports.

$\mathrm{H}_{0}: \sum_{j=1}^{p} \beta_{5 j}=0$ : Economic growth does not Granger cause re-exports.

$\mathrm{H}_{\mathrm{A}}: \sum_{j=1}^{p} \beta_{5 j} \neq 0$ : Economic growth Granger causes re-exports.

\subsubsection{Long-run Granger Causality Test}

This paper applies the modified version of the Granger causality test (MWALD) proposed by Toda and Yamamoto (1995), involving the following model:

$$
\begin{aligned}
& L Y_{t}=\alpha_{10}+\sum_{j=1}^{p+d \max } \beta_{1 j} L Y_{t-j}+\sum_{j=1}^{p+d \max } \gamma_{1 j} L K_{t-j}+\sum_{j=1}^{p+d \max } \delta_{1 j} L H C_{t-j}+\sum_{j=1}^{p+d \max } \zeta_{1 j} L N O I L X_{t-j} \\
& +\sum_{j=1}^{p+d \max } \theta_{1 j} \operatorname{LREX}_{t-j}+\sum_{j=1}^{p+d m a x} \mu_{1 j} \operatorname{LIMP} P_{t-j}+\varepsilon_{1 t} \\
& L K_{t}=\alpha_{20}+\sum_{j=1}^{p+d m a x} \beta_{2 j} L Y_{t-j}+\sum_{j=1}^{p+d m a x} \gamma_{2 j} L K_{t-j}+\sum_{j=1}^{p+d m a x} \delta_{2 j} L H C_{t-j}+\sum_{j=1}^{p+d m a x} \zeta_{2 j} L_{N O I L X} \\
& +\sum_{j=1}^{p+d \max } \theta_{2 j} \operatorname{LREX}_{t-j}+\sum_{j=1}^{p+d \max } \mu_{2 j} \operatorname{LIMP} P_{t-j}+\varepsilon_{2 t} \\
& L H C_{t}=\alpha_{30}+\sum_{j=1}^{p+d m a x} \beta_{3 j} L Y_{t-j}+\sum_{j=1}^{p+d m a x} \gamma_{3 j} L K_{t-j}+\sum_{j=1}^{p+d m a x} \delta_{3 j} L H C_{t-j}+\sum_{j=1}^{p+d m a x} \zeta_{3 j} L N O I L X_{t-j} \\
& +\sum_{j=1}^{p+d \max } \theta_{3 j} L R E X_{t-j}+\sum_{j=1}^{p+d \max } \mu_{3 j} L I M P_{t-j}+\varepsilon_{3 t} \\
& \text { LNOILX }_{t}=\alpha_{40}+\sum_{j=1}^{p+d \text { max }} \beta_{4 j} L Y_{t-j}+\sum_{j=1}^{p+d \text { max }} \gamma_{4 j} L K_{t-j}+\sum_{j=1}^{p+d m a x} \delta_{4 j} L H C_{t-j}+\sum_{j=1}^{p+d m a x} \zeta_{4 j} L N O I L X_{t-j} \\
& +\sum_{j=1}^{p+d \max } \theta_{4 j} \operatorname{LREX}_{t-j}+\sum_{j=1}^{p+d \max } \mu_{4 j} \operatorname{LIMP}_{t-j}+\varepsilon_{4 t} \\
& \operatorname{LREX}_{t}=\alpha_{50}+\sum_{j=1}^{p+d \max } \beta_{5 j} L Y_{t-j}+\sum_{j=1}^{p+d \max } \gamma_{5 j} L K_{t-j}+\sum_{j=1}^{p+d \max } \delta_{5 j} L H C_{t-j}+\sum_{j=1}^{p+d \max } \zeta_{5 j} L_{\text {LNOILX }} \text { D }_{t-j} \\
& +\sum_{j=1}^{p+d \max } \theta_{5 j} \operatorname{LREX}_{t-j}+\sum_{j=1}^{p+d \max } \mu_{5 j} \operatorname{LIMP} P_{t-j}+\varepsilon_{5 t}
\end{aligned}
$$




$$
\begin{aligned}
\operatorname{LIMP}_{t} & =\alpha_{60}+\sum_{j=1}^{p+d \max } \beta_{6 j} L Y_{t-j}+\sum_{j=1}^{p+d \max } \gamma_{6 j} L K_{t-j}+\sum_{j=1}^{p+d m a x} \delta_{6 j} L H C_{t-j}+\sum_{j=1}^{p+d m a x} \zeta_{6 j} L_{N O I L X_{t-j}} \\
& +\sum_{j=1}^{p+d \max } \theta_{6 j} \operatorname{LREX}_{t-j}+\sum_{j=1}^{p+d \operatorname{dmax}} \mu_{6 j} L I M P_{t-j}+\varepsilon_{6 t}
\end{aligned}
$$

where $p$ is the optimal lag length, selected by minimising the value of SIC, while $d_{\max }$ is the maximum order of integration of the variables in the model. In particular, the selected lag length $(p)$ is augmented by the maximum order of integration $\left(d_{\max }\right)$ and the chi-squared test is applied to the first $\mathrm{p}$ VAR coefficients.

\section{Empirical Results}

\subsection{Unit Root Tests}

Table 2 presents the results of the ADF, PP and SL unit root tests at levels and first differences. The results suggest that all variables are $I(1)$ and therefore the cointegration test can be applied in order to investigate the existence of a long-run relationship between the variables.

\begin{tabular}{|c|c|c|c|c|c|c|}
\hline \multirow[b]{3}{*}{$L Y$} & \multirow{3}{*}{$\begin{array}{l}\text { ADF test } \\
-3.45^{*(a)} \\
{[0]}\end{array}$} & \multirow{3}{*}{$\begin{array}{l}\text { PP test } \\
-3.41^{*(a)} \\
\{3\}\end{array}$} & \multicolumn{4}{|c|}{ SL test } \\
\hline & & & \multicolumn{2}{|c|}{ Without trend } & \multicolumn{2}{|c|}{ With trend } \\
\hline & & & $\begin{array}{l}0.77 \\
{[0]}\end{array}$ & 1990 & $\begin{array}{l}-1.09 \\
{[0]}\end{array}$ & 1986 \\
\hline$\Delta L Y$ & $\begin{array}{l}-4.32^{* * *(b)} \\
{[0]}\end{array}$ & $\begin{array}{l}-4.30^{* * *(b)} \\
\{1\}\end{array}$ & $\begin{array}{l}-5.14^{* * *} \\
{[0]}\end{array}$ & 1986 & $\begin{array}{l}-4.50^{* * *} \\
{[0]}\end{array}$ & 1990 \\
\hline$L K$ & $\begin{array}{l}-2.36^{(\mathrm{a})} \\
{[0]}\end{array}$ & $\begin{array}{l}-2.36^{(\mathrm{a})} \\
\{6\}\end{array}$ & $\begin{array}{l}0.11 \\
{[0]}\end{array}$ & 2001 & $\begin{array}{l}-1.45 \\
{[0]}\end{array}$ & 2001 \\
\hline$\Delta L K$ & $\begin{array}{l}-4.84^{* * *(c)} \\
{[0]}\end{array}$ & $\begin{array}{l}-4.88^{* * *(c)} \\
\{2\}\end{array}$ & $\begin{array}{l}-4.85^{* * *} \\
{[0]}\end{array}$ & 2001 & $\begin{array}{l}-4.95^{* * *} \\
{[0]}\end{array}$ & 2001 \\
\hline LHC & $\begin{array}{l}-2.02^{(\mathrm{a})} \\
{[1]}\end{array}$ & $\begin{array}{l}5.84^{(\mathrm{c})} \\
\{1\}\end{array}$ & $\begin{array}{l}0.05 \\
{[1]}\end{array}$ & 2008 & $\begin{array}{l}-2.64 \\
{[1]}\end{array}$ & 2008 \\
\hline$\Delta L H C$ & $\begin{array}{l}-3.04^{* *(b)} \\
{[0]}\end{array}$ & $\begin{array}{l}-3.04^{* *(b)} \\
\{3\}\end{array}$ & $\begin{array}{l}-3.75^{* * *} \\
{[1]}\end{array}$ & 2008 & $\begin{array}{l}-3.46^{* *} \\
{[1]}\end{array}$ & 2008 \\
\hline LNOILX & $\begin{array}{l}-1.94^{(\mathrm{a})} \\
{[0]}\end{array}$ & $\begin{array}{l}-1.86^{(\mathrm{a})} \\
\{3\}\end{array}$ & $\begin{array}{l}0.85 \\
{[0]}\end{array}$ & 1988 & $\begin{array}{l}-2.50 \\
{[0]}\end{array}$ & 1999 \\
\hline$\Delta L N O I L X$ & $\begin{array}{l}-8.75^{* * *(b)} \\
{[0]}\end{array}$ & $\begin{array}{l}-8.55^{* * *(b)} \\
\{2\}\end{array}$ & $\begin{array}{l}-5.93^{* * *} \\
{[0]}\end{array}$ & 1987 & $\begin{array}{l}-5.11^{* * *} \\
{[0]}\end{array}$ & 1987 \\
\hline LREX & $\begin{array}{l}-3.06^{(a)} \\
{[1]}\end{array}$ & $\begin{array}{l}-3.06^{(a)} \\
\{3\}\end{array}$ & $\begin{array}{l}-1.05 \\
{[0]}\end{array}$ & 1987 & $\begin{array}{l}-1.72 \\
{[1]}\end{array}$ & 1985 \\
\hline$\Delta L R E X$ & $\begin{array}{l}-6.38^{* * *(b)} \\
{[0]}\end{array}$ & $\begin{array}{l}-8.63^{* * *(b)} \\
\{16\}\end{array}$ & $\begin{array}{l}-6.79^{* * *} \\
{[0]}\end{array}$ & 1987 & $\begin{array}{l}-6.86^{* * *} \\
{[0]}\end{array}$ & 1987 \\
\hline LIMP & $\begin{array}{l}-2.91^{(\mathrm{a})} \\
{[0]}\end{array}$ & $\begin{array}{l}-2.92^{(\mathrm{a})} \\
\{2\}\end{array}$ & $\begin{array}{l}0.50 \\
{[0]}\end{array}$ & 2001 & $\begin{array}{l}-1.24 \\
{[0]}\end{array}$ & 2001 \\
\hline$\Delta L I M P$ & $\begin{array}{l}-3.81^{* * *(b)} \\
{[0]}\end{array}$ & $\begin{array}{l}-3.72^{* * *(b)} \\
\{2\}\end{array}$ & $\begin{array}{l}-7.41^{* * *} \\
{[7]}\end{array}$ & 2001 & $\begin{array}{l}-6.92^{* * *} \\
{[7]}\end{array}$ & 2001 \\
\hline
\end{tabular}

Table 2: ADF, PP and SL test results at logarithmic level and first difference $(\Delta)$. 
Notes: ${ }^{*}, * * * * *$ denote the rejection of the null hypothesis of a unit root at $10 \%, 5 \%$ and $1 \%$, respectively. Numbers in [] corresponding to ADF and SL test statistics are the optimal lags, chosen based on the Schwarz information criterion (SIC). Bandwidth in \{\} (Newey-West automatic) using the Bartlett kernel estimation method. The maximum lag length for the ADF test is found by rounding up $P_{\max }=\left[12^{*}\right.$ $\left.(\mathrm{T} / 100)^{1 / 4}\right]=\left[12^{*}(32 / 100)^{1 / 4}\right] \approx 9$ (Schwert 1989). For the ADF and PP tests, all the time series are tested for the unit root including intercept and trend (a), intercept only (b), and no intercept or trend (c). The letters in parentheses indicate the selected model following Dolado, Jenkinson, and Sosvilla-Rivero (1990). Critical values for the SL test are tabulated in Lanne, Lütkepohl, and Saikkonen (2002). The years in the table refer to the shift dummy variable $d_{1 \mathrm{t}}$ with break date $T_{\text {break }}: d_{1 \mathrm{t}}=0$, for $t<T_{\text {break }}$ and $d_{1 \mathrm{t}}=1$, for $t>T_{\text {break }}$ in equations 10 and 11 .

\subsection{Cointegration Test}

The Johansen cointegration test ${ }^{3}$ is conducted in order to investigate the existence of a long-run relationship between the variables. Table 3 shows that the null hypothesis of no cointegration is rejected at the $1 \%$ significance level, indicating the existence of one cointegrating vector.

Table 3: Johansen's cointegration test results.

\begin{tabular}{lllll}
\hline Hypothesized number of cointegrating equations & Adjusted trace statistic & \multicolumn{2}{c}{ Critical value } \\
\cline { 2 - 5 } & & $\mathbf{1 \%}$ & $\mathbf{5 \%}$ & $\mathbf{1 0} \%$ \\
\hline$r=0$ & $133.39^{* * * *}$ & 111.01 & 102.14 & 97.18 \\
$r \leq 1$ & 70.71 & 84.45 & 76.07 & 71.86 \\
$r \leq 2$ & 40.89 & 60.16 & 53.12 & 49.65 \\
$r \leq 3$ & 24.45 & 41.07 & 34.91 & 32.00 \\
\hline
\end{tabular}

Note: Critical values are taken from Osterwald-Lenum (1992). The model includes a restricted constant (model selection based on Pantula 1989). The lag length for the cointegration test is determined by minimizing the Schwarz information criterion (SIC), while the diagnostic tests reveal that the residuals are multivariate normal, homoscedastic with no evidence of serial correlation. * ** and ${ }^{* * *}$ indicate rejection at $10 \%, 5 \%$ and $1 \%$, respectively.

The cointegrating vector is estimated after normalizing on $L Y$, and the following long-run relationship is obtained. The absolute $t$-statistics are reported in the parentheses and ${ }^{* * *}$ indicates rejection at the $1 \%$ significance level:

$$
\begin{array}{rllll}
L Y_{t} & =0.565 L K_{t} & -0.531 L H C_{t} & +0.221 \text { LNOILX }_{t} & +0.750 L R E X_{t} \\
& (12.322)^{* * *} & (7.019)^{* * *} & (4.771)^{* * *} & (15.888)^{* * *} \\
& & & \\
& -0.556 L I M P_{t} & +11.567 & & \\
& (8.078)^{* * *} & (25.111)^{* * *} &
\end{array}
$$

From the above equation, a $1 \%$ increase in real non-oil exports leads to a $0.221 \%$ increase in real GDP, while a $1 \%$ increase in re-exports raises real GDP by $0.750 \%$. In addition, real GDP increases by $0.565 \%$ in response to a $1 \%$ increase in physical capital. In contrast, a $1 \%$ increase in population and imports leads to a decrease in real GDP by $0.531 \%$ and $0.556 \%$, respectively. These results suggest that both categories of diversified exports enhance economic growth in the UAE, with re-exports contributing more than non-oil exports in the long-run.

\subsection{Granger Causality in a VECM Framework}

The short-run Granger causality results ${ }^{4}$ for the UAE are reported in Table 4 . The results show that the null hypothesis that non-oil exports and re-exports do not cause economic growth cannot be rejected at any conventional significance level. In addition, the null hypothesis that economic growth does not Granger cause non-oil exports and the null hypothesis that economic growth does not Granger cause re-exports cannot be rejected. Therefore, there are no direct causal relationships between economic growth and non-oil exports and between economic growth and re-exports in the short-run.

Table 4: Short-run Granger causality test results.

\begin{tabular}{ll}
$\begin{array}{l}\text { Dependent } \\
\text { variable }\end{array}$ & Source of causality \\
\cline { 2 - 2 }
\end{tabular}




\begin{tabular}{|c|c|c|c|c|c|c|c|}
\hline & $\Delta L Y_{t}$ & $\Delta L K_{t}$ & $\underline{\Delta L H C_{t}}$ & $\Delta L N O I L X_{t}$ & $\Delta L R E X_{\mathrm{t}}$ & $\Delta^{\Delta L I M P_{t}}$ & $A L L$ \\
\hline & $\chi^{2}(1)$ & $\chi^{2}(1)$ & $\chi^{2}(1)$ & $\chi^{2}(1)$ & $\chi^{2}(1)$ & $\chi^{2}(1)$ & $\chi^{2}(5)$ \\
\hline$\Delta L Y_{t}$ & - & 0.181 & 0.301 & 2.403 & 1.631 & 0.178 & 6.813 \\
\hline$\Delta L K_{t}$ & $5.676^{* *}$ & - & 0.000 & 0.413 & 0.177 & 0.000 & $9.369^{*}$ \\
\hline$\Delta L H C_{t}$ & 0.093 & 2.503 & - & 0.539 & 0.010 & 0.413 & 3.225 \\
\hline$\Delta L N O I L X_{t}$ & 0.456 & 0.073 & $5.509^{* *}$ & - & $2.764^{*}$ & 0.023 & $30.304^{* * *}$ \\
\hline$\Delta L R E X_{t}$ & 1.361 & $3.250^{*}$ & $13.455^{* * *}$ & $20.138^{* * *}$ & - & $16.453^{* * *}$ & $38.403^{* * *}$ \\
\hline$\Delta L I M P_{t}$ & $4.141^{* *}$ & 0.213 & 0.769 & 0.122 & 0.176 & - & $9.986^{*}$ \\
\hline
\end{tabular}

Note: ${ }^{*}{ }^{* *}$ and ${ }^{* * *}$ indicates significance at $10 \%, 5 \%$ and $1 \%$, respectively. The lag length for the VECM is determined by minimizing the Schwarz information criterion (SIC). The diagnostic tests for the VECM model show that there is an absence of serial correlation, while the residuals are multivariate normal and homoscedastic. In addition, the stability of the VECM is confirmed by calculating the inverse roots of the characteristic AR polynomial. Df in parentheses.

It should be noted, however, that an indirect short-run causal relationship exists between economic growth and re-exports, through physical capital accumulation and imports. In particular, economic growth Granger causes physical capital at the 5\% significance level and physical capital Granger causes re-exports at the 10\% significance level. At the same time, economic growth Granger causes imports at the 5\% significance level and imports Granger cause re-exports at the $1 \%$ significance level. Therefore, economic growth indirectly causes re-exports in the short-run, through physical capital accumulation and imports.

Since the aim of this research is to focus on the relationship between exports and economic growth, emphasis is placed on the structural stability of the parameters of the estimated ECMs for economic growth and diversified exports (eqs. (21), (24), (25)). The CUSUM plots (Figure 2) for the estimated ECM for economic growth (Figure 2(a)), non-oil exports (Figure 2(b)) and re-exports (Figure 2(c)) show that there is no movement outside the $5 \%$ critical lines. Therefore, the estimated ECMs for economic growth and diversified exports, including the impulse dummy for the year 2000, are stable. Thus, there is no reason to test for the presence of a second structural break.

(a)
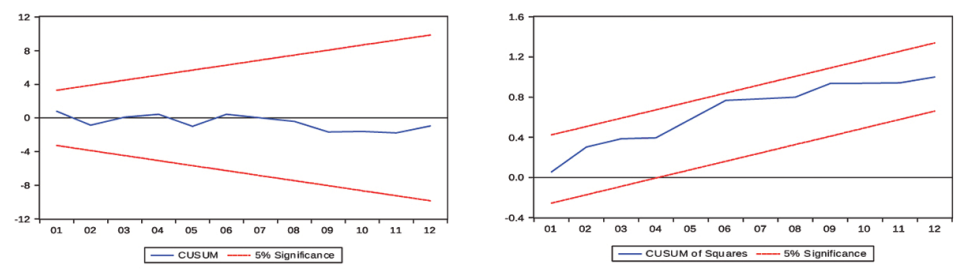

$\Delta L Y_{t}=0.274 \Delta L Y_{t-1}+0.048 \Delta L K_{t-1}-0.117 \Delta L H C_{t-1}+0.080 \Delta L N O I L X_{t-1}+0.085 \Delta L R E X_{t-1}+0.065 \Delta L I M P_{t-1}$ $+0.152 D U M 00-0.114 E C T_{t-1}$

(b)
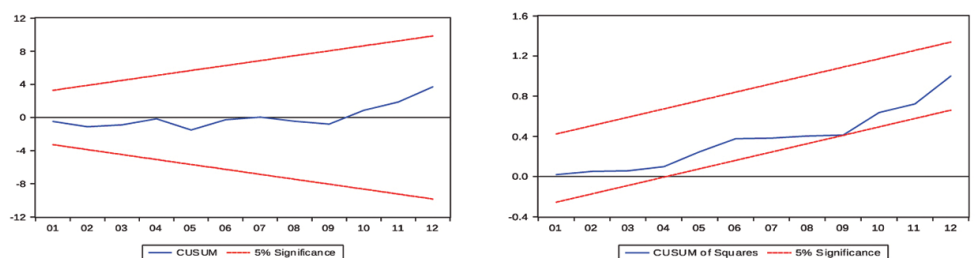

$\Delta L N O I L X_{t}=0.44 \Delta L Y_{t-1}-0.122 \Delta L K_{t-1}+1.992 \Delta L H C_{t-1}-0.641 \Delta L N O I L X_{t-1}+0.43 \Delta L R E X_{t-1}-0.093 \Delta L I M P_{t-1}$ $-0.474 D U M 00-0.104 E C T_{t-1}$

(c)
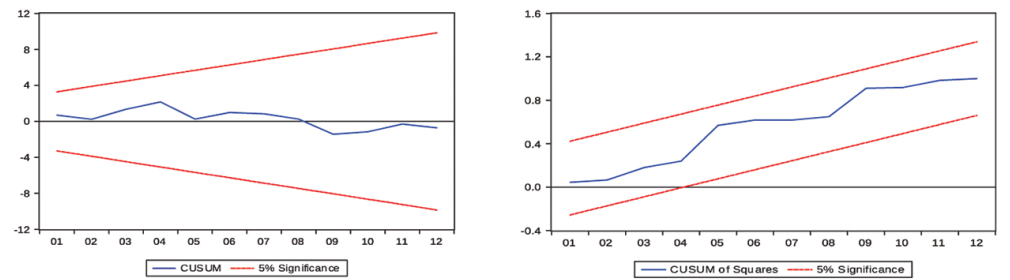

$\Delta L R E X_{t}=0.421 \Delta \mathrm{LY}_{\mathrm{t}-1}-0.447 \Delta L K_{t-1}-1.712 \Delta L H C_{t-1}+0.505 \Delta L N O I L X_{t-1}+0.503 \Delta L R E X_{t-1}+1.370 \Delta L I M P_{t-1}$ $+0.343 D U M 00+1.623 E C T_{t-1}$

Figure 2: Plot of CUSUM and CUSUMQ for the estimated ECM for economic growth, non-oil exports and re-exports. 


\subsection{Toda-Yamamoto-Granger Causality Test}

The maximum order of integration of the variables is $d_{\max }=1$, while the optimal lag length, based on the SIC, is one. Therefore the selected lag length $(p=1)$ is augmented by the maximum order of integration $\left(d_{\max }=1\right)$ and the modified Wald tests are applied to the first $\mathrm{p}$ VAR coefficients. The results are presented in Table 5.

Table 5: Granger causality based on the Toda-Yamamoto procedure.

\begin{tabular}{|c|c|c|c|c|c|c|c|}
\hline \multirow{3}{*}{$\begin{array}{l}\text { Dependent } \\
\text { variable }\end{array}$} & \multicolumn{7}{|c|}{ Source of causality } \\
\hline & $L Y_{t}$ & $L K_{t}$ & $L H C_{t}$ & LNOILX $_{t}$ & $L_{R E X_{t}}$ & $\operatorname{LIMP}_{t}$ & $A L L$ \\
\hline & $\chi^{2}(1)$ & $\chi^{2}(1)$ & $\chi^{2}(1)$ & $\chi^{2}(1)$ & $\chi^{2}(1)$ & $\chi^{2}(1)$ & $\chi^{2}(5)$ \\
\hline$L Y_{t}$ & - & 1.633 & 0.563 & 0.003 & $3.709^{*}$ & 0.322 & 8.052 \\
\hline$L K_{t}$ & $3.795^{*}$ & - & 0.030 & 0.049 & 0.088 & 0.010 & 5.367 \\
\hline $\mathrm{LHC}_{t}$ & 0.558 & 2.003 & - & 0.209 & 1.280 & 1.163 & 3.019 \\
\hline LNOILX $_{t}$ & 0.099 & 0.284 & 2.214 & - & 1.004 & 0.006 & 5.512 \\
\hline$L_{R E X_{t}}$ & $5.324^{* *}$ & $8.225^{* * *}$ & $2.881^{*}$ & 1.064 & - & $13.893^{* * *}$ & $19.751^{* * *}$ \\
\hline$L I M P_{t}$ & 1.210 & 0.547 & 0.377 & 0.763 & 0.434 & - & 6.884 \\
\hline
\end{tabular}

Note: ${ }^{* * *}$ and ${ }^{* * *}$ indicate significance at $10 \%, 5 \%$ and $1 \%$, respectively. The diagnostic tests for the select VAR(p) model prior to the application of the Toda-Yamamoto procedure show that there is no problem with serial correlation, while the residuals are multivariate normal and homoscedastic. Df in parentheses.

The results of the modified Wald tests indicate that LREX Granger causes $L Y$ at the $10 \%$ significance level, while $L Y$ Granger causes LREX at the 5\% significance level, indicating that a bi-directional causal relationship exists between $L Y$ and LREX. These results show that economic growth can cause an increase in re-exports, by increasing the inflow of investments to the re-exports sector and improving the existing technology. At the same time, the expansion of re-exports increases the inflows of foreign exchange, leading to economic growth. Moreover, economic growth indirectly causes re-exports in the long-run, through physical capital. In particular, $L Y$ Granger causes $L K$ at the $10 \%$ significance level and $L K$ Granger causes $L R E X$ at the $1 \%$ significance level.

\section{Conclusions}

The empirical results show that GDP, physical capital, human capital, non-oil exports, re-exports and imports are cointegrated, while no causality exists between non-oil exports or re-exports and economic growth in the short-run. However, an indirect causality exists between economic growth and re-exports through physical capital and imports. In addition, there is evidence to support the existence of a bi-directional causality between re-exports and economic growth in the long-run, which is consistent with Tuan and Ng's (1998) results for Hong Kong. Thus, re-exports is the only export category that causes economic growth in the UAE in the long-run.

This suggests that a further increase in the degree of export diversification from oil could accelerate economic growth in the UAE. However, emphasis should be placed on physical and human capital accumulation, as these factors directly cause re-exports, fostering further economic growth in the long-run. In parallel, programs that enhance UAE competitiveness should be implemented, as re-exports can be easily displaced by competition (Haddad 2000).

Finally, it is interesting to note that the value of re-exports to the GCC region comprises $13.95 \%$ of total reexports, while the value of re-exports to Iran and Iraq comprises $23.69 \%$ of the total. Within Europe, Belgium and Switzerland rank first, as the value of re-exports to these countries together comprises approximately $9 \%$ of total re-exports. Moreover, $39.71 \%$ of total re-exports comprises pearls, precious stones and precious metals, followed by machinery (20.8\%) and transport vehicles (16.2\%). Re-exports cause long-run economic growth in the UAE, but which of these categories of re-exports and which export destinations offer the greatest potential for sustainable economic growth? Future research in this area would include investigating the causality between disaggregated re-exports, export destination diversification and economic growth. Doing so will help in the design of future policies for achieving sustainable economic growth in resource-abundant countries such as the UAE.

Conflict of Interest: The author declares that they have no conflict of interest. 


\section{Notes}

1 The trace statistic is adjusted by using the correction factor $\left(T-n^{*} p\right) / T$ proposed by Reinsel and Ahn (1992), where $T$ is the sample size, while $n$ and $p$ are the number of variables and optimal lag length, respectively.

2 Diagnostic tests are conducted in order to determine whether the models are well specified and stable. These tests include the JarqueBera normality test, the Portmanteau and Breusch-Godfrey LM tests for the existence of autocorrelation, the White heteroskedasticity test, the multivariate $\mathrm{ARCH}$ test and the AR roots stability test.

3 The model is estimated with the inclusion of an impulse dummy variable (DUM00) for the year 2000, as the CUSUMQ plot of the initially estimated ECM for economic growth showed evidence of structural instability. In the second half of 2000, due to the production cuts by OPEC, the oil price increased by approximately two hundred percent compared with the 1999 level, reaching more than US $\$ 30$ per barrel. 4 The VECM is estimated with the inclusion of an impulse dummy variable for the year 2000, as the CUSUMQ plot of the initially estimated ECM for economic growth shows evidence of structural instability. The estimated ECM without the inclusion of the dummy variable is not reported here, but is available upon request.

\section{References}

Abu-Qarn, Aamer S., and Suleiman Abu-Bader. 2004. “The Validity of the ELC Hypothesis in the MENA Region: Cointegration and Error Correction Model Analysis." Applied Economics 36 (15): 1685-95.

Al-Yousif, Yousif K. 1997. “Exports and Economic Growth: Some Empirical Evidence from the Arab Culf Countries." Applied Economics 29 (6): 693-97.

Awokuse, Titus O. 2003. “Is the Export-Led Crowth Hypothesis Valid for Canada?” Canadian Journal of Economics 36 (1): 126-36.

Awokuse, Titus O. 2007. "Causality between Exports, Imports and Economic Growth: Evidence from Transition Economies." Economics Letters 94 (3): 389-95.

Berrill, Kenneth E. 1960. “International Trade and the Rate of Economic Growth." Economic History Review 12 (3): 351-59.

Brown, Robert L., James Durbin, and John M. Evans. 1975. "Techniques for Testing the Constancy of Regression Relationships over Time." Journal of the Royal Statistical Society 37 (2): 149-92.

Chaudhuri, Pramit. 1989. The Economic Theory of Crowth. London: Harvester Wheatsheaf.

Chenery, Hollis B., and Alan M. Strout. 1966. "Foreign Assistance and Economic Development." American Economic Review 56 (4): $679-733$

Dolado, Juan, Tim Jenkinson, and Simon Sosvilla-Rivero. 1990. “Cointegration and Unit Roots." Journal of Economic Surveys 4 (3): $249-73$.

Elbeydi, Khaled R. M., Abdulbaset M. Hamuda, and Vladimir Gazda. 2010. "The Relationship between Export and Economic Crowth in Libya Arab Jamahiriya." Theoretical and Applied Economics 17 (1): 69-76.

El-Sakka, Mohammed I., and Naief H. Al-Mutairi. 2000. “Exports and Economic Growth: the Arab Experience." Pakistan Development Review 39 (2): 153-69.

Enders, Walter. 1995. Applied Econometric Time Series. New York: Wiley.

Ferreira, Gustavo F. 2009. “The Expansion and Diversification of the Export Sector and Economic Growth: the Costa Rican Experience." PhD diss., Louisiana State University.

Gbaiye, Oluwaseun C., Adeyemi Ogundipe, Evans Osabuohien, Oluseyi O. Olugbire, Odunola A. Adeniran, Kofo A. Bolaji-Olutunji, Oluwakemi D. Awodele, and Oluwatomi Aduradola. 2013. "Agricultural Exports and Economic Crowth in Nigeria (1980-2010)." Journal of Economics and Sustainable Development 4 (16): 1-5.

Chatak, Subrata, Chris Milner, and Utku Utkulu. 1997. "Exports, Export Composition and Crowth: Cointegration and Causality Evidence for Malaysia." Applied Economics 29 (2): 213-23.

Cranger, Clive W. J. 1969. "Investigating Causal Relations by Economic Models and Cross-Spectral Models." Econometrica 37 (3): 424-38.

Cranger, Clive W. J. 1988. "Some Recent Development in a Concept of Causality." Journal of Econometrics 39 (1-2): 199-211.

Gujarati, Damodar N. 2003. Basic Econometrics, 4th ed. Boston: McGraw-Hill.

Cylfason, Thorvaldur. 1999. “Exports, Inflation and Growth." World Development 27 (6): 1031-57.

Haddad, Mona. 2000. “Export Competitiveness: Where Does the Middle East and North Africa Region Stand?" Economic Research Forum Working Paper Series No. 2030.

Herzer, Dierk, Felicitas D. Nowak-Lehmann, and Boriss Siliverstovs. 2006. “Export-Led Growth in Chile: Assessing the Role of Export Composition in Productivity Crowth." The Developing Economies 44 (3): 306-28.

Hosseini, Seyed M. P., and Chor F. Tang. 2014. “The Effects of Oil and Non-Oil Exports on Economic Growth: A Case Study of the Iranian Economy." Economic Research-Ekonomska Istraživanja 27 (1): 427-41.

Johansen, Soren. 1988. "Statistical Analysis of Cointegrating Vectors." Journal of Economic Dynamics and Control 12 (2-3): 231-54.

Johansen, Soren. 1995. Likelihood-based Inference in Cointegrated Vector Autoregressive Models. Oxford: Oxford University Press.

Jung, Woo S., and Peyton J. Marshall. 1985. "Exports, Growth and Causality in Developing Countries." Journal of Development Economics 18 (1): $1-12$.

Kalaitzi, Athanasia S. 2018. "The Causal Effects of Trade and Technology Transfer on Human Capital and Economic Growth in the United Arab Emirates." Sustainability 10 (5): 1-15.

Kalaitzi, Athanasia S., and Emmanuel Cleeve. 2017. "Export-Led Growth in the UAE: Multivariate Causality between Primary Exports, Manufactured Exports and Economic Growth." Eurasian Business Review 8 (3): 341-65.

Katircioglu, Salih, Setareh Katircioglu, and Ozlem Altun. 2018. "The Moderating Role of Oil Price Changes in the Effects of Service Trade and Tourism on Crowth: The Case of Turkey." Environmental Science and Pollution Research 25: 35266-75.

Kim, Dong-Hyeon, and Shu-Chi Lin. 2009. "Trade and Growth at Different Stages of Economic Development." The Journal of Development Studies 45 (8): 1211-24. 
Kwan, Andy C. C., and John A. Cotsomitis. 1991. "Economic Growth and the Expanding Export Sector: China 1952-1985." International Economic Journal 5 (1): 105-16.

Lanne, Markku, Helmut Lütkepohl, and Pentti Saikkonen. 2002. “Comparison of Unit Root Tests for Time Series with Level Shifts.” Journal of Time Series Analysis 23: 667-85.

Lee, Chien-Hui, and Bwo-Nung Huang. 2002. "The Relationship between Exports and Economic Growth in East Asian Countries: A Multivariate Threshold Autoregressive Approach." Journal of Economic Development 27 (2): 45-68.

Love, Jim, and Ramesh Chandra. 2005. "Testing the Export-Led Growth in South Asia." Journal of Economic Studies 32 (2): 132-45.

Meier, Cerald M. 1970. Leading Issues in Economic Development. Oxford: Oxford University Press.

Mishra, P. K. 2011. “Exports and Economic Growth: Indian Scene.” SCMS Journal of Indian Management 8 (2): 17-26.

Myrdal, Gunnar. 1957. Economic Theory and Under-developed Regions. London: Gerald Duckworth and Co.

Osterwald-Lenum, Michael. 1992. "A Note with Quantiles of the Asymptotic Distribution of the Maximum Likelihood Cointegration Rank Test Statistics." Oxford Bulletin of Economics and Statistics 54 (3): 461-72.

Panas, Epaminondas, and Ceorge Vamvoukas. 2002. "Further Evidence on the Export-Led Crowth Hypothesis." Applied Economics Letters 9 (11): 731-35.

Pantula, Sastry C. 1989. “Testing for Unit Roots in Time Series Data." Econometric Theory 5 (2): 256-71.

Phillips, Peter C. B., and Pierre Perron. 1988. "Testing for a Unit Root in Time Series Regression." Biometrika 75 (2): $335-46$.

Ramos, Francisco R. 2001. "Exports, Imports, and Economic Growth in Portugal: Evidence from Causality and Cointegration Analysis." Economic Modelling 18 (4): 613-23.

Reinsel, Gregory C., and Sung K. Ahn. 1992. “Vector Autoregressive Models with Unit Roots and Reduced Rank Structure: Estimation, Likelihood Ratio Tests and Forecasting." Journal of Time Series Analysis 13 (4): 353-75.

Rodrik, Dani. 1997. “Trade Strategy, Investment, and Exports: Another Look at East Asia." Pacific Economic Review 2 (1): 1-24.

Saikkonen, Pentti, and Helmut Lütkepohl. 2002. "Testing for a Unit Root in a Time Series with a Level Shift at Unknown Time." Econometric Theory 18 (2): 313-48.

Schwert, William G. 1989. “Test for Unit Roots: A Monte Carlo Investigation.” Journal of Business and Economic Statistics 7 (2): $147-59$.

Shirazi, Nasim S., and Turkhan A. Abdul Manap. 2004. "Exports and Economic Growth Nexus: the Case of Pakistan." Pakistan Development Review 43 (4): 563-81.

Siliverstovs, Boriss, and Dierk Herzer. 2006. "Export-Led Crowth Hypothesis: Evidence for Chile." Applied Economics Letters 13 (5): 319-24.

Sims, Christopher A. 1980. "Macroeconomics and Reality." Econometrica 48 (1): 1-48.

Sodeyfi, Setareh, and Salih Katircioglu. 2016. "Interactions between Business Conditions, Economic Growth and Crude Oil Prices." Economic Research-Ekonomska Istraživanja 29 (1): 980-90.

Tang, Tuck C. 2006. "New Evidence on Export Expansion, Economic Growth and Causality in China." Applied Economics Letters 13 (12): 801-03.

Toda, Hiro Y., and Taku Yamamoto. 1995. "Statistical Inferences in Vector Autoregressions with Possibly Integrated Processes." Journal of Econometrics 66 (1-2): 225-50.

Tuan, Chyau, and Linda F. Y. Ng. 1998. “Export Trade, Trade Derivatives, and Economic Growth of Hong Kong: A New Scenario." Journal of International Trade \& Economic Development 7 (1): 111-37.

Verbeek, Mano J. C. M. 2012. A Cuide to Modern Econometrics, 4th ed. Chichester: John Wiley and Sons.

World Trade Organization. World Trade Policy Review: United Arab Emirates Geneva: World Trade Organization 2012. 